\title{
Free adrenaline and noradrenaline excretion related to occupational stress
}

\author{
MARIO TIMIO, SIMONETTA GENTILI, AND SERGIO PEDE \\ From Institute of Patologia Speciale Medica e Metodologia Clinica, University of Perugia, Policlinico \\ Monteluce, Perugia, Italy
}

SUMMARY Urinary levels of free adrenaline and noradrenaline were measured in two groups of healthy male industrial workers exposed to alternate four-day periods of working conditions with and without time stress, to test the hypothesis that the sympathetic nervous system is overactivated by occupational stress. Thirty confectionery workers alternated piece-work (payment by results) and work with a fixed daily wage while 30 metal workers alternated work on an assembly line with work off it. Under time stress urinary free adrenaline was 450 per cent and noradrenaline 230 per cent of the levels for similar work without time stress but involving equal oxygen consumption. These differences were statistically highly significant and they persisted on retesting after six months of alternating work regimens. They support the concept that occupational stress in industrial workers influences the adrenosympathetic system and they indicate a possible method for assessing the effects of high levels of sympathetic activity on the aetiology of ischaemic heart disease.

Urinary free adrenaline and noradrenaline excretion provides a general measure of sympatho-adrenal response to stress (von Euler, 1964). This measurement has been used by Bellet et al. (1969), Anitesco (1972), Klimmer (1972), Levi (1972b), and Carruthers et al. (1976) to evaluate the role of the sympathetic nervous system in some forms of occupational stress. However, few attempts have been made to assess adrenosympathetic activity in certain common types of work, such as piece-work and on the assembly-line.

The purpose of the present study was to extend our earlier observations (Timio and Gentili, 1976) to a larger group of workers, with particular reference to assessing the role of the sympathetic nervous system by contrasting measurements of urinary free adrenaline and noradrenaline excretion in men under conditions of time stress at work (piece-work and on the assembly-line) with similar work without time stress. In addition this study was designed to ascertain whether the adrenosympathetic reaction becomes altered after a six-month period of intermittent exposure to both work systems.

\section{Subiects and methods}

Sixty male industrial workers took part in this research. The age range was 22 to 42 years, mean 34 years. All subjects were in good health and had

Received for publication 26 January 1979 normal 12 lead electrocardiogram, blood pressure, and glomerular filtration rate (performed a few days before the observation). The aim and procedure of the study were explained to all workers and their signed consent obtained.

They were divided into two groups according to their job:

Group 1: 30 confectionery workers (pieceworkers, paid by results);

Group 2: 30 metal workers (assembly-line workers).

They were all trained. All had worked at the same trade for more than one year, predominantly on piece-work or on the assembly-line. To avoid the possibility that the hormonal response of the workers might have been conditioned in advance because we had told them the aim of the study, a cross-over design was used, dividing each group into two subgroups of 15 workers. Each subgroup was investigated for three periods of four consecutive working days (seven hours daily) according to the following schedules.

Schedule $A$ : the first subgroup of confectionery workers started under piece-work conditions, continued on a fixed daily wage, then performed piece-work again (piece-work/fixed wage/piecework).

Schedule $B$ : the second subgroup of confectionery workers, after the first period on a fixed wage, continued on piece-work, and then returned to a 
fixed wage (fixed wage/piece-work/fixed wage).

Schedule $C$ : the first subgroup of metal workers worked on the assembly-line, performed work off the assembly-line during the second period, and then returned to the assembly-line (assembly-line/ off-the-line/assembly-line).

Schedule $D$ : the second subgroup of metal workers began with off-the-line work, continued on the assembly-line, then performed off-the-line work again (off-the-line/assembly-line/off-the-line).

Muscular work expressed as average energy cost $\left(\mathrm{MJ} /\right.$ minute $\left.^{1}\right)$ was similar on piece-work $(7 \cdot 35 \pm$ $0.50)$ and fixed wage days $(7 \cdot 30 \pm 0.46)$, and on assembly-line $(8 \cdot 10 \pm 0.76)$ and off-the-line work days $(8 \cdot 15 \pm 0 \cdot 80)$. Energy expenditure was calculated in terms of the oxygen consumed in litres of expired air per minute ( 1 litre of oxygen consumed by a worker is equivalent to $21 \mathrm{MJ}$ ). The expired air was collected in a Douglas bag for 10 minutes of every workday of a given task (Zenz, 1975).

To minimise methodological errors we adopted a standard procedure. During the periods of observation food intake was free of any substance that might have influenced urinary catecholamine excretion; all drinks containing ethanol or caffeine were prohibited. No worker was taking psychotrophic substances, oral sympathomimetics, or sympathicolytics, tetracyclines, or inhaled vasoconstrictor substances for nasal stuffiness.

Each subject was instructed not to smoke from the time he awoke to the end of his working day. Working environmental temperature was constant at optimal levels $\left(17^{\circ}\right.$ to $\left.20^{\circ} \mathrm{C}\right)$.

Each worker started work at 7.00 am after an overnight rest and a standard breakfast. Each emptied his bladder some five to 10 minutes before he started work. Urine collections were made over the seven-hour working period in bottles containing $10 \mathrm{ml} 6 \mathrm{~N} \mathrm{HCl}$ and stored at $4^{\circ} \mathrm{C}$. The storage period never lasted more than 24 hours.

Determinations of urinary excretion of free adrenaline and noradrenaline were made blind, using the spectrofluorimetric method described by Valori et al. (1970). The quantity of each amine was estimated differentially by solving two simultaneous equations in which fluorescence readings were corrected for the blank values. However, in our procedure, reagent blank values were low, reproducible, and very stable. In order to compensate for any incomplete urine collections, the catecholamine results were expressed as $\mu \mathrm{g}$ per $\mathbf{g}$ creatinine, as suggested by von Euler (1964). Creatinine was determined by alkaline picrate method.

Student's $\mathrm{t}$ test for paired data was used for $1 \mathrm{kCal} \approx 4 \cdot 2 \mathrm{MJ}$. statistical analysis. All values are given as mean \pm standard error of means. Serial determinations of free adrenaline and noradrenaline urinary excretion were repeated in the same subjects after six months, during which time they alternated weeks under time-stress in piece-work or on the assembly-line with weeks of fixed wages or off-the-line work. The standard procedure, cross-over design, and chemical method were identical to those adopted for the first observation.

\section{Results}

\section{STANDARD GROUP}

The urinary excretion of adrenaline and noradrenaline in 10 male normal control subjects (age range: 24 to 43 years, mean age 33) during 7 hours (from $7.00 \mathrm{am}$ to $2.00 \mathrm{pm}$ ) of light work was for adrenaline: $1.24 \pm 0.51 \mu \mathrm{g} / \mathrm{g}$ creatinine; and for noradrenaline: $7 \cdot 19 \pm 1 \cdot 1 \mu \mathrm{g} / \mathrm{g}$ creatinine.

\section{GROUP 1}

The seven-hour adrenaline and noradrenaline excretion in the confectionery workers increased steadily throughout the four days of piece-work, during both A and B schedules; the mean levels are presented in Table 1. During fixed wage days the urinary levels of adrenaline and noradrenaline were low and did not differ from those in the control

Table 1 Mean levels $( \pm S E M)$ for urinary adrenaline and noradrenaline excretion ( $\mu / g$ creatinine $/ 7 h$ ) during four-day periods of piece-work and fixed wages in schedules $A$ and $B$

\begin{tabular}{|c|c|c|c|c|c|}
\hline \multirow{2}{*}{ Schedule } & \multirow{2}{*}{ Work } & \multicolumn{2}{|c|}{ Adrenaline } & \multicolumn{2}{|c|}{ Noradrenaline } \\
\hline & & Mean \pm & $S E M$ & Mean \pm & $S E M$ \\
\hline A & $\begin{array}{l}\text { Piece-work } \\
\text { Fixed wage } \\
\text { Piece-work }\end{array}$ & $\begin{array}{l}5 \cdot 83 \\
1 \cdot 12 \\
5 \cdot 36\end{array}$ & $\begin{array}{l}0.98 \\
0.27 \\
1.01\end{array}$ & $\begin{array}{r}20.02 \\
8 \cdot 12 \\
18.83\end{array}$ & $\begin{array}{l}1.82 \\
0.78 \\
1.96\end{array}$ \\
\hline B & $\begin{array}{l}\text { Fixed wage } \\
\text { Piece-work } \\
\text { Fixed wage }\end{array}$ & $\begin{array}{l}1 \cdot 28 \\
6 \cdot 03 \\
1 \cdot 11\end{array}$ & $\begin{array}{l}0 \cdot 39 \\
1 \cdot 18 \\
0 \cdot 44\end{array}$ & $\begin{array}{r}10 \cdot 04 \\
22 \cdot 19 \\
9 \cdot 15\end{array}$ & $\begin{array}{l}0.62 \\
2 \cdot 31 \\
1.01\end{array}$ \\
\hline
\end{tabular}

Table 2 Mean levels ( \pm SEM) of urinary adrenaline and noradrenaline excretion ( $\mu \mathrm{g} / \mathrm{g}$ creatinine $/ 7 \mathrm{~h}$ ) during four-day periods of piece-work and fixed wages in schedules $A$ and $B$ in same workers after six months

\begin{tabular}{llllrl}
\hline \multirow{2}{*}{ Schedule } & Work & \multicolumn{2}{l}{ Adrenaline } & \multicolumn{2}{c}{ Noradrenaline } \\
\cline { 3 - 6 } & & \multicolumn{2}{l}{ Mean \pm SEM } & \multicolumn{2}{c}{ Mean \pm SEM } \\
\hline \multirow{3}{*}{ A } & Piece-work & 4.29 & 0.83 & 23.19 & 2.98 \\
& Fixed wage & 1.01 & 0.21 & 9.01 & 1.12 \\
& Piece-work & 5.18 & 1.12 & 19.13 & 2.01 \\
& Fixed wage & 1.61 & 0.39 & 8.16 & 0.98 \\
& Piece-work & 6.13 & 2.01 & 22.58 & 2.11 \\
& Fixed wage & 1.18 & 0.19 & 10.01 & 1.09 \\
\hline
\end{tabular}


men doing light work. The differences between piece-work and fixed wage periods in both subgroups were highly significant $(P<0.001)$.

After six months, the measurement of excreted free adrenaline and noradrenaline again showed raised levels in both subgroups of confectionery workers during the four days of piece-work compared with the fixed wage periods (Table 2). The change was statistically significant $(P<0.01)$.

\section{GROUP 2}

During each period of assembly-line work performed in accordance with schedules $C$ and $D$, the mean seven-hour levels of urinary adrenaline and noradrenaline in metal workers were significantly higher $(P<0.01)$ than those found during off-theline work (Table 3 ). The excretion of both catecholamines was similar to the value of control men doing light work at all times of off-the-line work.

Table 3 Mean levels ( \pm SEM) of urinary adrenaline and noradrenaline excretion ( $\mu \mathrm{g} / \mathrm{g}$ creatinine $/ 7 \mathrm{~h}$ ) during four-day periods of assembly-line and off-the-line work in schedule $C$ and $D$

\begin{tabular}{lllllll}
\hline \multirow{2}{*}{ Schedule } & Work & \multicolumn{2}{l}{ Adrenaline } & \multicolumn{2}{l}{ Noradrenaline } \\
\cline { 3 - 6 } & & \multicolumn{2}{l}{ Mean \pm SEM } & \multicolumn{2}{c}{ Mean \pm SEM } \\
\hline \multirow{4}{*}{ C } & Assembly-line & 5.53 & 1.08 & 21.13 & 2.96 \\
& Off-the-line & 1.08 & 0.22 & 9.11 & 1.36 \\
& Assembly-line & 6.01 & 1.12 & 19.18 & 2.49 \\
& Off-the-line & 1.17 & 0.28 & 8.06 & 1.14 \\
D & Assembly-line & 5.13 & 1.06 & 21.38 & 2.07 \\
& Off-the-line & 1.04 & 0.23 & 10.12 & 1.35 \\
\hline
\end{tabular}

Measurement of urinary free adrenaline and noradrenaline after six months showed a high level throughout each period of assembly-line work, compared with low values obtained during off-theline work (Table 4). The difference was significant $(P<0.01)$ for both catecholamines.

Table 4 Mean levels ( \pm SEM) of urinary adrenaline and noradrenaline excretion ( $\mu \mathrm{g} / \mathrm{g}$ creatinine $/ 7 \mathrm{~h}$ ) during four-day period of assembly-line and off-the-line work in schedules $C$ and $D$ in same workers after six months

\begin{tabular}{lllllll}
\hline \multirow{2}{*}{ Schedule } & Work & \multicolumn{2}{l}{ Adrenaline } & \multicolumn{2}{l}{ Noradrenaline } \\
\cline { 3 - 6 } & & \multicolumn{2}{l}{ Mean \pm SEM } & \multicolumn{2}{c}{ Mean \pm} & SEM \\
\hline & & 6.14 & 1.96 & 19.46 & 2.04 \\
C & Assembly-line & 1.26 & 0.33 & 10.13 & 1.14 \\
& Off-the-line & 1.36 & 1.68 & 21.16 & 2.48 \\
& Assembly-line & 5.36 & & & \\
D & Off-the-line & 1.04 & 0.19 & 10.18 & 1.06 \\
& Assembly-line & 4.93 & 1.51 & 23.72 & 3.12 \\
& Off-the-line & 1.22 & 0.25 & 8.41 & 0.97 \\
\hline
\end{tabular}

\section{Discussion}

The aim of the present study was to describe the effects of two common working systems with respect to the adrenosympathetic response which they produced in men.

The results extend our earlier report (Timio and Gentili, 1976) and represent the first serial measurement of adrenaline and noradrenaline during piecework and assembly-line work. They support the assumption that such working factors have a significant effect on the sympathetic function in normal subjects. A previous investigation consisted of a few measurements of urinary catecholamines performed by Levi (1972b) in 12 healthy female invoicing clerks, under experimental conditions very similar to piece-work. He found a significant increase in urinary adrenaline and noradrenaline excretion, with a concomitant increase in distress, as judged by increment in rush, fatigue, and physical discomfort ratings.

In 60 healthy male blue-collar workers under piece-work and assembly-line conditions, we have observed an increase in the urinary level of free adrenaline and noradrenaline. The increase remained almost unchanged $(450 \%$ and $230 \%$ of the mean normal values) thoughout the four days of observation. During fixed wage days and off-theline work, measurements of both catecholamines were low and equalled those of controls doing light work, though the muscular work (as measured by oxygen consumption) of confectionery workers and metal workers was identical to that on days of piece-work and assembly-line work.

The difference in urinary catecholamine excretion between the two time stressed and unstressed working conditions persisted not only throughout each four-day period of observation, but also after six months of alternate exposure to time stress and unstressed working conditions.

The basic physiological mechanisms leading to the high levels of catecholamines in these subjects, to some degree accustomed to their routine, are not straightforward, since habituation to normal environmental stimuli might be expected to lead to a decrease in psychoendocrine reaction intensity (Levi, 1972a). On the other hand, the possible effect on the adrenosympathetic response resulting from awareness of the aim of the investigation was avoided by a cross-over design involving the division of each group of workers into two subgroups with alternate schedules of work. One might hypothesise that the significant adrenosympathetic reaction occurring from a repetition of psychological working stress is the net effect of prolonged exposure (increasing the levels) 
and of habituation (decreasing the levels).

Analysis of multiple factors that promote adrenergic drive, quantification of their relative importance, and the identification of the source of the increased urinary excretion of catecholamines in normal subjects under conditions of work stress are difficult. Henry et al. (1971), studying the effects of environmental behavioural influences on the cardiovascular system, noted an increase in the catecholamine-synthesising enzyme tyrosine-hydroxylase and phenyletanolamine $\mathrm{N}$-methyltransferase in mice exposed for prolonged periods to substained psychosocial stress. Even though the experimental animal metabolic response to environmental stress may have aspects that mimic human conditions, the importance of these results, extrapolated to man, is only conjectural.

Although there is some experimental evidence to link increased adrenergic activity with the development of atherosclerosis and coronary heart disease (Haft and Fani, 1973), further research is needed to assess the suggestion that the adrenosympathetic overactivity observed in men under modern working conditions predisposes towards disease of the coronary arteries.

\section{References}

Anitesco, C. (1972). Study of the influence of noise and vibrations on the behaviour of catecholamines in industrial vibratory acoustic stress (in French). Archives des Maladies Professionnelles, 33, 365-370.

Bellet, S. I., Roman, L., and Kostis, J. (1969). The effect of automobile driving on catecholamine and adrenocortical excretion. American fournal of Cardiology, 24, 365-368.

Carruthers, M., Arguelles, A. E., and Mosovich, A. (1976). Man in transit: biochemical and physiological changes during inter-continental flights. Lancet, 1, 977-981.

Haft, J. I., and Fani, K. (1973). Intravascular platelet aggregation in the heart induced by stress. Circulation, 47, 358-359.

Henry, S. P., Stephens, P. M., Axelrod, S., and Mueller R. A. (1971). Effect of psychosocial stimulation on the enzymes involved in the biosynthesis and metabolism of noradrenaline and adrenaline. Psychosomatic Medicine, 33, 227-237.

Klimmer, F. (1972). Catecholamine excretion in the urine during mental work load in the air traffic control service. Internationales Archiv für Arbeitsmedizin, 30, 65-70.

Levi, L. (1972a). Methodological considerations in psychoendocrine research. Acta Medica Scandinavica, 191, Suppl. 528, 28-54.

Levi, L. (1972b). Conditions of work and sympathoadrenomedullary activity: experimental manipulations in a real life setting. Acta Medica Scandinavica, 191, Suppl. 528, 106-118.

Timio, M., and Gentili, S. (1976). Adrenosympathetic overactivity under conditions of work stress. British fournal of Preventive and Social Medicine, 30, 262-265.

Valori, C., Brunori, C. A., Renzini, V., and Corea, L. (1970). Improved procedure for formation of epinephrine and norepinephrine fluorophors by the trihydroxyindole reaction. Analytical Biochemistry, 33, 158-167.

Von Euler, U. S. (1964). Quantitation of stress by catecholamine analysis. Clinical Pharmacology and Therapeutics, 5, 398-404.

Zenz, C. (1975). Ergonics: work effort, determination of energy, expenditure and fatigue. In Occupational Medicine: Principles and Practical Applications, p. 423. Year Book Medical Publishers, Chicago.

Requests for reprints to Dr Mario Timio, Via 20 Settembre n. 22, 06100-Perugia, Italy. 